\title{
A pessoa humana: implicações de um conceito teológico para a compreensão do Ensino Religioso
}

\author{
Orientador: Joel Portella Amado \\ Doutoranda: Jacirema Maria Thimoteo dos Santos \\ Área de Concentração: Teologia Sistemático-Pastoral \\ Linha de Pesquisa: Religião e Modernidade
}

Inserida num conjunto de controvérsias a disciplina de Ensino Religioso é usualmente percebida como desnecessária ao sistema educacional brasileiro, passando por uma falta de compreensão e respeito por parte de muitos educadores e da própria sociedade. Vários motivos levam a este posicionamento, dentre eles a falta de uma identidade. A presente tese tem como objetivo propor uma identidade para o Ensino Religioso com base no olhar da Teologia, pautada no conceito cristão de pessoa. A partir dessa perspectiva, para a concretização desse objetivo, realizamos um estudo bibliográfico, como procedimentos metodológicos, para a fundamentação dos conceitos trabalhados, quais sejam: as cinco propostas curriculares existentes e utilizadas pelo sistema educacional brasileiro, as questões relativas ao estado laico, à liberdade religiosa, à relação entre religião e secularização e o conceito de pessoa para algumas Ciências e para o Cristianismo, bem como alguns conceitos relacionados à área pedagógica: educação, aluno, professor, currículo e metodologia. Os mesmos culminam em uma identidade e uma sugestão de proposta curricular para o Ensino Religioso condizente com o que a fé cristã entende por pessoa e a visão pedagógica e desafiadora da educação libertadora apresentada, que propõe uma práxis educativa dialógica, que leva em consideração àquele que é o cerne de todo processo ensino-aprendizagem: o aluno. Por fim, o trabalho busca apontar que o Ensino Religioso é um direito desse aluno, enquanto ser humano integral. Nesse sentido, o Ensino Religioso, enquanto confessional, plural e relacional pode ser uma contribuição inconteste para a Educação.

Palavras-chave: Ensino religioso. Teologia. Pessoa. 